兵庫医科大学血液内科

HLA 不適合移植（ハプロ移植）は，そのレジメンによって移植の様相は異なってくる。まず海外のハプロ移植と して，1）in vitroでのT細胞除去，2）high dose ATG，3）post-transplant cyclophosphamideを紹介する。報告に よればGVHDは十分にコントロールされ, 今後一般臨床として普及することが期待される一方, GVL効果は未知数 であり，主たる適応は寛解期の疾患である。一方本邦では，非寛解期や移植後再発に対して，ハプロ移植に期待する 傾向がある。我々が行っているステロイドを用いたハプロ移植もその一つであり, 最近はケモカイン阻害を rationale としている。またハプロ移植ではGVHDが重篤化しやすいため, 様々なGVHD治療を試みる機会は多い。本稿では サイモグロブリン, mycophenolate mofetil, infliximab, 経口Beclomethasone dipropionate, mesenchimal stromal cellについて，自らの印象を含めて記載した。(日本造血細胞移植学会誌２(4): 94-100, 2013.)

\section{諸言}

HLA はヒトMHCであり, 最大の移植拒絶抗原となる。 HLA 以外の抗原（マイナー抗原）に対する T細胞が 10 万 個に 1 個程度の頻度であるのに対し，アロMHCに対する $\mathrm{T}$ 細胞は数十〜百個に 1 個であるから, その免疫原性は文 字通りケタが違うということになる。トーマスが同種骨髄 移植を確立して以来,「HLA 適合ドナー」から移植すると いうことは, 同種造血幹細胞移植のセントラルドグマと なってきた。一方で, ドナープール拡大の要望や, 免疫抑 制剂を含めた支持療法の進歩により，HLA不適合造血幹 細胞移植も可能となってきた。現在, 血縁の HLA不適合 移植（実際的にはほとんどすべて HLA 半合致移植（ハプ 口移植）になるので同義語として用いる）においては，前 処置と幹細胞源, GVHD予防をセットとした種々のレジ メンが報告されている。本稿ではまず代表的な血縁 HLA 不適合移植レジメンに関する知見を紹介したい。なお本邦 におけるハプロ移植については, 我々の regimen 以外はそ れぞれの研究者の発表に委ね, 一部を紹介するにとどめる。 次にHLA不適合移植におけるGVHD治療について言及 した。HLA不適合移植においてひとたびGVHDが発症し た場合，その反応は激烈であることはしばしば経験され， それが今日までHLA不適合移植が忌避されてきた主因と なっている。しかしたとえHLA適合移植においても, いっ たん発症してしまったGVHDは，免疫抑制剤を極量投与
したとしても抑えられるという保証はない。このような GVHDの 1 次治療はステロイドであるが, 2 次治療として 確立されたものはない。むしろ, HLA不適合移植におい ては,「絶対にGVHDを起こさない」という心構えのほう が重要であり，GVH反応に対する早期介入の重要性を強 調すべきと考える。

なおハプロ移植の実臨床はいまだ歴史が浅く，すべてが 論文化あるいはエビデンスとして整理されているわけでは ないため, 本総説では敢えて筆者の経験や私見を盛り込ま せていただいた。

\section{HLA1 抗原不適合移植 (GVH方向に1抗原不適 合の場合)}

従来より血縁者間の HLA1 抗原不適合移植は, HLA 適 合移植と同じ範疇として許容されると考えられ，実際行 われてきた。血縁者間でのHLA適合移植と HLA1 抗原不 適合移植との比較では，理論的な予想通り，HLA1 抗原不 適合移植の方が，GVHDが増えるが，（GVL効果が増強 するため) 再発が減る ${ }^{1}$ 。従って, 生存率をエンドポイン トとしてみた場合，low riskの腫瘍に対してはHLA適合 移植のほうが良いが, high riskの腫瘍に対しては，相殺さ れて結果は同じくらいとなる。次に血縁者間 HLA1 抗原不 適合移植と非血縁者間 HLA適合移植の比較においては, かつての low resolutionでのHLAマッチングでは，血縁者

Submitted August 28, 2013; Accepted October 4; 2013

key words: HLA, haploidentical, ATG, PTCY, steriod

Correspondence: Kazuhiro Ikegame, MD., PhD. Division of Hematology, Department of Internal Medicine, Hyogo College of Medicine. 1-1 Mukogawa-cho, Nishinomiya City, Hyogo 663-8501, Japan. E-mail: kame@hyo-med.ac.jp. dx.doi.org/10.7889/hct.2.94 ㄷ The Japan Society for Hematopoietic Cell Transplantation. 
間の HLA1 抗原不適合移植の方が良かったが，最近の high resolutionによる，8/8ないし10/10アリル適合の非血縁バ ンクドナーからの移植では，こちらの方がGVHDが少な

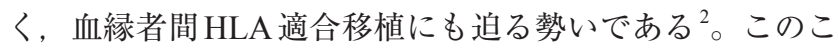
とからも, HLA1つの不適合と, それ以外のマイナー抗原 の不適合での圧倒的なマグニチュードの差がうかがえる。 このように血縁者間の HLA1 抗原不適合移植は実臨床とし て受け入れられてはいるが, その免疫反応は無視し得る ものではなく，血縁者間 HLA1 抗原不適合移植における至 適レジメン $(\mathrm{GVHD}$ 予防) は目下の課題と言える。国内 においても, HLA1抗原不適合移植はHLA適合移植の範 疇ととらえ, cyclosporine (CsA) + short term methotrexate (MTX) で行う施設と, GVHDケアを厚くするために tacrolimus（TAC） + short term MTXで行う施設があり, 施設の得意不得意も勘案すると優劣をつけられる状況には ない。

\section{HLA2-3抗原不適合，すなわち狭義での血縁 HLA 半合致移植（いわゆるハプロ移植）にお ける検討}

\section{海外におけるハプロ移植}

1）in vitroでの徹底した $\mathrm{T}$ 細胞除去（in vitro $\mathrm{T}$ cell depletion. in vitro TCD)

ペルージャを中心としたin vitro TCD 移植では，移植時 に混入する $\mathrm{T}$ 細胞を $10^{4} / \mathrm{kg}$ オーダーまで下げている。ここ まで下げると移植後にGVHD予防をなしにしてもGVHD は発症しないとされる。GVL効果はもっぱら NK細胞に 期待しており，詳細な検討がなされている。少なくとも初 期のペルージャからの報告では， NK alloreactivityのある AMLに対しては良好な成績が期待できるが，ALLに対す る治療成績は不良であった。またAML，ALLとも，非寛 解例に対しては太刀打ちできるものではなく，約 10 年の follow upでは, 非寛解期移植での生存率は20か月でプラ トーとなり, AMLで $18 \%, \mathrm{ALL} て ゙ 5 \%$ 生存率であった ${ }^{3} 。$ また移植後の感染症も課題となっている ${ }^{4-8}$ 。

2) High dose ATG

2-1）北京大学方式

北京大学から報告されているレジメンはcytosine arabinoside (CA)/busulfan (BU) /cyclophosphamide (CY) /Me-CCNU/ATG $10 \mathrm{mg} / \mathrm{kg}$ を前処置として, GVHD予防は CsA, short term MTX と mycophenolate mofetil (MMF) を用いている。加えて, 幹細胞源として G-CSF primed $\mathrm{BM}+\mathrm{PB}$ を用いている点が特徵である。彼らはこのことが 移植後のGVHDを起こしにくい要因になっていると主張
しているが9-13, 以下に述べる韓国からの報告を勘案すれ ば，ATG（サイモグロブリン）を $10 \mathrm{mg} / \mathrm{kg}$ 用いれば，それ だけもハプロ移植は可能であろうと思われる。実際，彼ら の論旨は，ハプロ移植がHLA 適合移植と同等に施行しう るということに力点が置かれており，その適応は宽解期の 症例が多い。一方，非寛解症例に対しては十分な成績は得 られておらず，予防的な donor lymphocyte infusion（DLI） （ここでも G-CSFでプライミングしたDLI）を行って，成 績の向上を目指しているようである。この報告によると, DLI をしなかった群では 2 年の再発率が $55 \% ， 3$ 年の生存 率が $11 \%$ であったのに対し，予防的DLIをした群では 2 年 の再発率が $36 \%, 3$ 年の生存率が $31 \%$ に改善されたとして いる ${ }^{12}$ 。

\section{2-2）韓国からの報告}

韓国からの血縁 HLA 半合致移植は比較的オーソドック スなものと言える。上述の北京方式による G-CSF primed $\mathrm{BM}+\mathrm{PB}$ は，必ずしも他施設には浸透していない部分も あるが，韓国からの報告は，この要素を取り除いており， シンプルにATGを十分に投与すれば，ハプロ移植は成立 することを示した。前処置はfludarabine (FLU) /BU/ATG を用い，GVHD予防はTACと short term MTXを用いて いる。ATGの量はサイモグロブリンで $12 \mathrm{mg} / \mathrm{kg}$ である。 幹細胞源は，通常の方法でドナーにG-CSFで動員した末 梢血幹細胞を凍結せずに用いている ${ }^{14} 83$ 人の患者にこの レジメンでハプロ移植を行い, 生着率 $92 \%$, 急性 GVHD （grade II-IV）の発症率は $20 \%$, 治療関連死亡は $18 \%$ あっっ た。26.6か月の follow upで，寛解期の移植では $50 \%$ 程度 の生存率を得ているが，非寛解期の疾患に対しては $9 \%$ と 不良であった。

\section{3) post-transplant CY (PTCY)}

最近，米国（Johns Hopkins）を中心に注目を浴びてい るレジメンである。「CYは活性化した T 細胞に優先的に殺 細胞効果をもつ」というコンセプトを基盤とする。移植後 早期に，不適合HLAのようなアロ抗原と出会って活性化 したドナー T細胞を標的とするため，移植後早期に比較 的大量の CY $(50 \mathrm{mg} / \mathrm{kg} /$ day *2days) を投与する方法であ る。これにより，併用する GVHD予防はCsA と short term MTXのみでも, 十分にGVHDをコントロールできている。 2 ユニットの臍帯血移植（dUCB）50例とPTCYのハプロ 移植（PTCY-haplo）50例（ほとんど寛解例, 少なくとも 急性白血病は全例寛解期の移植で, リンパ腫はdUCB群, PTCY-haplo 群とも 10 例程度の PR/resistantを含む) での比 較では，1年生存率がdUCB，PTCY-haploでそれぞれ $54 \%$ と $62 \%$ で同等であったが，その内訳として，1年無再発 
表1。T細胞除去をしないハプロ移植の報告例 ${ }^{\dagger}$

\begin{tabular}{|c|c|c|c|c|c|c|c|c|}
\hline Institute & $\mathrm{n}$ & Conditioning & $\begin{array}{l}\text { GVHD } \\
\text { propylaxis }\end{array}$ & NonCR & Engraftment & $\begin{array}{l}\text { GVHD } \\
\text { II-IV/III-IV }\end{array}$ & $\begin{array}{l}\text { OS (all) } \\
\text { OS (CR) } \\
\text { OS (nonCR) }\end{array}$ & Ref. \\
\hline \multicolumn{9}{|l|}{ Post-Cy } \\
\hline Baltimore & 68 & $\begin{array}{l}\text { FLU/Cy/ } \\
\text { TBI 2Gy }\end{array}$ & TAC/MMF & $24 \%$ & $87 \%$ & $34 \% / 6 \%$ & $\begin{array}{c}36 \% @ 2 y \\
- \\
-\end{array}$ & 16 \\
\hline Atranta & 20 & $\begin{array}{l}\text { FLU/BU/ } \\
\text { Cy }\end{array}$ & TAC/MMF & $0 \%$ & $100 \%$ & $30 \% / 10 \%$ & $\begin{array}{c}\text { 69\%@1y } \\
\text { 69\%@1y } \\
-\end{array}$ & 18 \\
\hline Genova & 50 & $\begin{array}{l}\text { FLU/BU/TT or } \\
\text { FLU/TBI9.9Gy }\end{array}$ & $\mathrm{CsA} / \mathrm{MMF}$ & $54 \%$ & $90 \%$ & $12 \% / 6 \%$ & $\begin{array}{c}- \\
\text { *68\%@1.5y } \\
\text { 37\%@1.5y }\end{array}$ & 20 \\
\hline \multicolumn{9}{|l|}{ ATG-base } \\
\hline Beijing & 756 & $\begin{array}{l}\text { CA/BU/Cy/ } \\
\text { MeCCNU/ATG }\end{array}$ & $\begin{array}{l}\text { CsA/MMF/ } \\
\text { MTX }\end{array}$ & $7 \%$ & $99 \%$ & $43 \% / 14 \%$ & $\begin{array}{c}\text { 67\%@3y } \\
- \\
\text { - }\end{array}$ & 13 \\
\hline Korea & 83 & FLU/BU/ATG & CsA/MTX & $49 \%$ & $92 \%$ & $20 \% / 7 \%$ & \begin{tabular}{l}
\multicolumn{1}{c}{} \\
60\%@3y \\
$9 \% @ 3 y$
\end{tabular} & 14 \\
\hline Japan & 34 & FLU/BU/ATG & TAC/mPSL & $88 \%$ & $100 \%$ & $32 \% / 24 \%$ & $\begin{array}{l}25 \% @ 3 y \\
75 \% @ 3 y \\
18 \% @ 3 y\end{array}$ & $\begin{aligned} & 26 \\
* & \text { DFS }\end{aligned}$ \\
\hline
\end{tabular}

In vivo TCDのレジメンは主として post-transplant CY (PTCY)を原理とするものと、ATGを用いるものに分かれる。オリジナルで あるJohns Hopkins のBaltimoreのグループは、ほとんどが寛解期の移植で 2 年生存率 $36 \%$ と報告し、成績自体は振るわないものの、 PTCYによりハプロ移植が成立することを示した。アトランタのグループは、寛解期症例であればPTCYでも 1 年生存率 $69 \%$ と良 好な成績を報告した。さらにジェノバのBacigalupo らのグループは前処置をフル移植にしたPTCYに変更し、非寛解期に対しても 1.5 年生存率 37\% と、希望のある成績を報告した。一方、ATGベースのハプロ移植はアジアからのものが多く、北京、韓国と我々のグルー プの成績を挙げてある。

†あるいは、ペルージャ方式の ex vivo T cell depletion (TCD)に対して、in vivo TCD とも呼ばれる

死亡率ではdUCB 24\%, PTCY-haplo 7\%であったのに対 し，1年再発率ではdUCB 31\%, PTCY-haplo 45\%であり， PTCY-haploは治療関連死亡が少ないけど再発が多い, low risk low returnの移植といえそうである ${ }^{15-19}$ 。一方, 最近 イタリアのBacigalupoらもこのタイプの移植成績を発表 しており, 非寛解期に対しても22 か月の無病生存率 $37 \%$ と比較的良好な成績であった ${ }^{20}$ 。オリジナルであるJohns Hopkins との違いは, 前処置がフルかミニかの違いであり, Johns Hopkins がFLU/ (少量 CY) /BU2/TBI2Gyであるの に対し, Bacigalupoらの前処置はThiotepa/FLU/BU3また はFLU/TBI 9.9Gyである。前処置強度を上げれば, 確か にある一定割合の患者層に対して有効なことは期待しうる が, 特に本邦では強いGVL効果をハプロに期待しており, 通常の意味でのハイリスク（同種移植適応）を超えた症例 に対してハプロの需要があると思われる。このような本来 ハプロ移植に期待される患者群に対して, PTCY regimen がどの程度通用するかどうかが，今後明らかになってくる と思われる。

\section{海外のハプロ移植の到達点}

海外におけるハプロ移植は1）徹底した T細胞除去 (Perugia), 2) high dose ATG (Beijing, Korea), 3) posttransplant CY（Johns Hopkins）に集約される。これらは 安全にハプロ移植を実施することを目標としたものであ り，事実GVHDはバンク移植や臍帯血移植と同程度まで 抑えられているが，GVL効果はバンク移植や臍带血移植 と同等かむしろそれ以下となっている。したがって，寛解 期での移植としては有用であるが，非寛解期の疾患に対し ての成績は不良である。（表1）

\section{本邦におけるハプロ移植}

4) noninherited maternal antigens (NIMA) 移植

母児間免疫寛容を利用したハプロ移植である。GVHD予 防はTACと short term MTXを用いている。この下で grade II - IV の急性GVHDの発症率は $30 \%$ 程度と報告されてい る ${ }^{21}$ 。NIMA 移植がGVHDの軽減につながることは報告さ れている ${ }^{22}$ が, GVL効果に与える影響を直接検討した報告 はなく，今後の検討が待たれる。母児間免疫寛容に関して は，様々な分野からこれにまつわる報告が出ており，単に 
ハプロ移植の成立機序にとどまらず，臍带血移植や臟器移 植, 免疫疾患等にも応用可能な概念であり, 興味が尽きない。

5）alemtuzumabを用いた移植

TCDを用いない移植（T cell replete移植）に扔いては, post-transplant CYを除いては, ATG baseのレジメンが趨 勢を占めている。このATGの代わりに, alemtuzumabを 用いて，T細胞を中心としたドナー由来の免疫担当細胞を 抑制する移植が神田らにより報告されている ${ }^{23}$ 。GVHD予 防はCsA と short term MTXが用いられる。最近, 再生不 良性貧血にも alemtuzumabを用いたハプロ移植が行われて おり，その安全性は確固としたものとなってきている ${ }^{24}$ 。 今後は alemtuzumabの用量調整によるハイリスク疾患への さらなる成績向上が期待される。

\section{6）大阪大/兵庫医大方式}

小川らが, かつて大阪大学, 現在は兵庫医科大学で行っ ている方法である。いくつかのレジメンの変遷を経たもの の, 共通する特徵は, GVHD予防としてステロイドを最 初から入れていることである。GVHDの発症にケモカイ ン/サイトカインが重要な役割を負っていることは周知の 事実であるが，カルシニューリン阻害剤で $\mathrm{T}$ 細胞の活性化 を抑えるとともに，ステロイドでGVHD標的臟器での炎 症を抑えることにより, ケモカイン/サイトカイン産生を 最小限にするという発想である。 $(25,26)$ このことにつ いては, 我々のグループのハプロ移植の rationale としてい ることなので，以下に再掲したい。

\section{— chemokine blockade-}

（急性）GVHDの病態生理に関する一連のシナリオは, まずドナーのリンパ球が2次リンパ組織で活性化し増殖す る。この時, GVHD標的臟器での炎症によって, ケモカ イン/サイトカインが産生され, このケモカインによって 活性化したドナー $\mathrm{T}$ 細胞が各標的臟器に移動して, その 臓器を障害する。従来から 2 次リンパ組織における $\mathrm{T}$ 細胞 の活性化や増殖においてGVHD と GVLを分ける様々な試 みがなされてきたが，いまだ臨床に応用できるほどに確立 したものはない。一方GVHDの発症に扔けるケモカイン の重要性はますます注目されつつある。ミシガンからの報

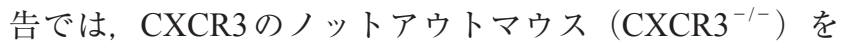
ドナーとして移植を行った時の, 組織へのT細胞浸潤数を 検討している。これによると，2次リンパ組織である脾臓 でのT細胞は野生型に比較して, $\mathrm{CXCR}^{-/-}$をドナーとし た方が多いのに対して，GVHD標的臟器である腸管では $\mathrm{CXCR}^{-1-}$ のT細胞浸潤は少なく, GVHDも軽かった ${ }^{27}$ 。 また最近，ヒトの系では，CCR5アンタゴニストを通常の
ミニ移植に併用することにより，腸管及び肝臟の GVHD が著明に減ったことが確認された ${ }^{28}$ 。我々の用いているス テロイドは2次リンパ組織に扔ける $\mathrm{T}$ 細胞活性化抑制とい うょりも，GVHD標的臟器での炎症を抑えることでケモ カイン産生を少なくして，GVHDを起こすドナーT細胞 のリクルートを減らすことが主体かもしれない。GVLに 扔けるサイトカイン/ケモカインの依存性はGVHDほどに は明らかでないと思っていて ${ }^{29,30}$, ここにGVHD/GVLの separationの隙間を期待している。

\section{HLA 不適合移植における GVHD 治療}

HLA不適合移植に打ける急性GVHDの 1 次治療は, HLA 適合移植と同様にステロイドである。実際には methylpredonisolone $1-2 \mathrm{mg} / \mathrm{kg} / \mathrm{day}$ 程度を用いられること が多い。ステロイドパルスについては血栓性微小血管障害,

（TMA）をきたすことが多いことから ${ }^{31}$ ，その使用には賛 否両論がある。

2次治療としては，保険適応のある抗 T細胞抗体（サイ モグロブリン)が挙げられる。抗 T細胞抗体は, 皮膚, 肝臓, 腸管のいずれの急性GVHDにも有効と思われるが, (図 1) その使用量は, 添付文書どおりだと多すぎるのではないか, との意見がある。通常 $0.5-1 \mathrm{mg} / \mathrm{kg}$ の一回投与で，末梢血 リンパ球は翌日には $100 / \mu 1$ 程度まで減少する。頻回の投与 は, ウイルス感染や再発の憂き目に会う（会った）ので, GVHDだけでなく，GVLや感染に対する免疫も抑えてし まうと感じる。

MMF は保険適応はまだないものの, 実際の臨床現場で はGVHDの予防および治療として，しばしば用いられて いる。著効例もなくはないが，効果は一般にマイルドであ り，単剤よりは他㓲，例えばステロイドの節約効果が期待 される。TMAの副作用はないが ${ }^{31}$, 骨髄抑制が問題となる。 infliximabはもともとの適応である炎症性腸疾患の類推 から，腸管GVHDに試されることが多い。有効例では極 めてキレのよい効き方をすることが経験されるが，論文上 ネガティブな結果が報告され ${ }^{32}$, 保険適応がないことから, その使用は限定的となっている。

経口 Beclomethasone dipropionate（BDP）は上部消化管 GVHDに対する液剤と，下部消化管GVHDに対する腸溶 剤カプセルとして用いる。治療に用いる場合は, 軽症の上 部消化管GVHDに対してが，最も効果があるようである が，BDPカプセルの不用意な中止で下痢をきたすことも 経験されるので，それなりに効果を実感させられる。ただ し重症の消化管GVHDに対する治療効果は限定的と思わ れる。

mesenchimal stromal cell (MSC) は最初の印象的な Lancetの報告 ${ }^{33}$ およびその続報 ${ }^{34}$ 以降, 国内外で使用経験 
ATG投与前

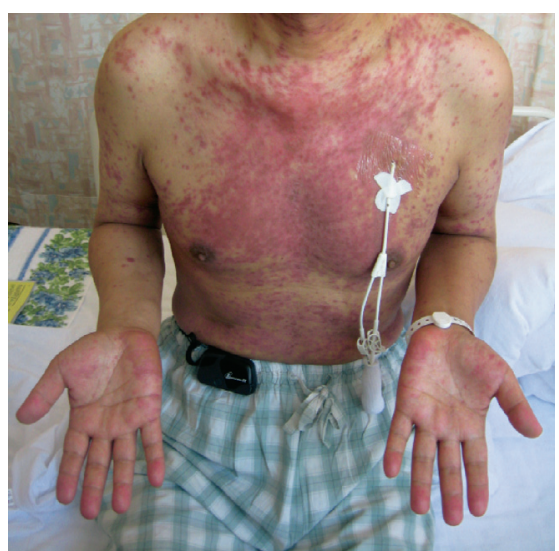

PSL 120mg/day ( + mPSL 500mg)

$+$

tacrolimus po (4-5 $\mathrm{ng} / \mathrm{ml})$
ATG投与後

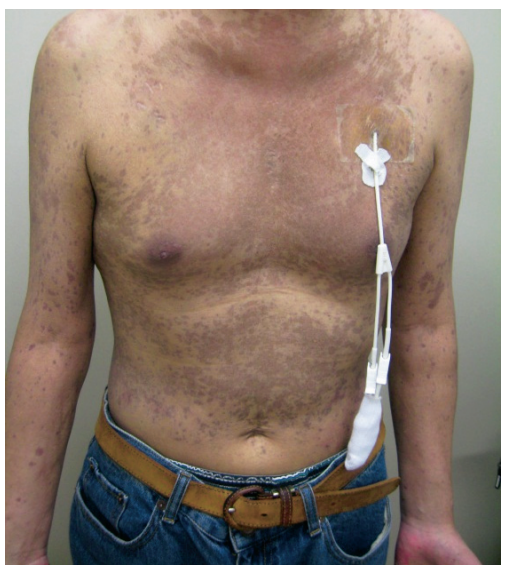

PSL 20mg/day

$+$

tacrolimus po (3-4 ng/ml)

図1. 皮膚GVHD に対するATGの効果

ATG 投与前（左図）では、PSL $120 \mathrm{mg} /$ day とTAC（血中濃度 $4-5 \mathrm{ng} / \mathrm{ml}$ ）の併用下でも活動性のある紅色の皮膚 GVHDがみられるが、ATG 投与後（右図）では、皮疹は褐色化し、免疫抑制剂の必要量もPSL $20 \mathrm{mg} / \mathrm{day}$ とTAC (血中濃度 $3-4 \mathrm{ng} / \mathrm{ml}$ ) まで減量可能となった。

が蓄積されてきている。まだロット間にばらつきはあるも のの, HLA不適合移植においてもおおむね良好な成績が 発表されつつあり，今後有望な治療として期待される。

\section{利益相反}

本論文に関して申告すべき利益相反はない。

\section{謝辞}

本稿にあたり，これまで多くの症例をともに経験してき た先輩，同僚，後輩および病棟スタッフ達に感謝します。 またハプロ移植を確立し，ご指導いただいた小川啓恭教授 に深謝いたします。

\section{参考文献}

1. Kanda Y, Chiba S, Hirai H, et al. Allogeneic hematopoietic stem cell transplantation from family members other than HLA-identical siblings over the last decade (1991-2000). Blood. 2003; 102: 1541-1547.

2. Kanda J, Saji H, Fukuda T, et al. Related transplantation with HLA-1 Ag mismatch in the GVH direction and HLA-8/8 allele-matched unrelated transplantation: a nationwide retrospective study. Blood. 2012; 119: 2409-2416.

3. Aversa F, Reisner Y, Martelli MF. Hematopoietic stem cell transplantation from alternative sources in adults with highrisk acute leukemia. Blood Cells Mol Dis. 2004; 33: 294-302.

4. Aversa F, Tabilio A, Terenzi A, et al. Successful engraftment of T-cell-depleted haploidentical "three-loci" incompatible transplants in leukemia patients by addition of recombinant human granulocyte colony-stimulating factor-mobilized peripheral blood progenitor cells to bone marrow inoculum. Blood. 1994; 84: 3948-3955.

5. Aversa F, Tabilio A, Velardi A, et al. Treatment of high-risk acute leukemia with T-cell-depleted stem cells from related donors with one fully mismatched HLA haplotype. N Engl J Med. 1998; 339: 1186-1193.

6. Ruggeri L, Capanni M, Urbani E, et al. Effectiveness of donor natural killer cell alloreactivity in mismatched hematopoietic transplants. Science. 2002; 295: 2097-2100.

7. Aversa F, Terenzi A, Tabilio A, et al. Full haplotypemismatched hematopoietic stem-cell transplantation: a phase II study in patients with acute leukemia at high risk of relapse. J Clin Oncol. 2005; 23: 3447-3454.

8. Ruggeri L, Mancusi A, Capanni M, et al. Donor natural killer cell allorecognition of missing self in haploidentical hematopoietic transplantation for acute myeloid leukemia: challenging its predictive value. Blood. 2007; 110: 433-440.

9. Ji SQ, Chen HR, Wang HX, et al. G-CSF-primed haploidentical marrow transplantation without ex vivo $\mathrm{T}$ cell depletion: an excellent alternative for high-risk leukemia. Bone Marrow Transplant. 2002; 30: 861-866.

10. $\mathrm{Lu} \mathrm{DP}$, Dong $\mathrm{L}, \mathrm{Wu} \mathrm{T}$, et al. Conditioning including antithymocyte globulin followed by unmanipulated HLAmismatched/haploidentical blood and marrow transplantation can achieve comparable outcomes with HLA-identical sibling transplantation. Blood. 2006; 107: 3065-3073.

11. Huang XJ, Zhu HH, Chang YJ, et al. The superiority of haploidentical related stem cell transplantation over chemotherapy alone as postremission treatment for patients 
with intermediate- or high-risk acute myeloid leukemia in first complete remission. Blood. 2012; 119: 5584-5590.

12. Wang Y, Liu DH, Xu LP, et al. Prevention of relapse using granulocyte CSF-primed PBPCs following HLA-mismatched/ haploidentical, T-cell-replete hematopoietic SCT in patients with advanced-stage acute leukemia: a retrospective riskfactor analysis. Bone Marrow Transplant. 2012; 47: 10991104.

13. Wang Y, Liu DH, Liu KY, et al. Long-term follow-up of haploidentical hematopoietic stem cell transplantation without in vitro $\mathrm{T}$ cell depletion for the treatment of leukemia: nine years of experience at a single center. Cancer. 2013; 119: 978985.

14. Lee KH, Lee JH, Lee JH, et al. Reduced-intensity conditioning therapy with busulfan, fludarabine, and antithymocyte globulin for HLA-haploidentical hematopoietic cell transplantation in acute leukemia and myelodysplastic syndrome. Blood. 2011; 118: 2609-2617.

15. O’Donnell PV, Luznik L, Jones RJ, et al. Nonmyeloablative bone marrow transplantation from partially HLA-mismatched related donors using posttransplantation cyclophosphamide. Biol Blood Marrow Transplant. 2002; 8: 377-386.

16. Luznik L, O’Donnell PV, Symons HJ, et al. HLAhaploidentical bone marrow transplantation for hematologic malignancies using nonmyeloablative conditioning and highdose, posttransplantation cyclophosphamide. Biol Blood Marrow Transplant. 2008; 14: 641-650.

17. Kasamon YL, Luznik L, Leffell MS, et al. Nonmyeloablative HLA-haploidentical bone marrow transplantation with highdose posttransplantation cyclophosphamide: effect of HLA disparity on outcome. Biol Blood Marrow Transplant. 2010; 16: 482-489.

18. Solomon SR, Sizemore CA, Sanacore M, et al. Haploidentical transplantation using $\mathrm{T}$ cell replete peripheral blood stem cells and myeloablative conditioning in patients with high-risk hematologic malignancies who lack conventional donors is well tolerated and produces excellent relapse-free survival: results of a prospective phase II trial. Biol Blood Marrow Transplant. 2012; 18: 1859-1866.

19. Brunstein CG, Fuchs EJ, Carter SL, et al. Alternative donor transplantation after reduced intensity conditioning: results of parallel phase 2 trials using partially HLA-mismatched related bone marrow or unrelated double umbilical cord blood grafts. Blood. 2011; 118: 282-288.

20. Raiola AM, Dominietto A, Ghiso A, et al. Unmanipulated haploidentical bone marrow transplantation and posttransplantation cyclophosphamide for hematologic malignancies after myeloablative conditioning. Biol Blood Marrow Transplant. 2013; 19: 117-122.

21. Ichinohe $T$, Uchiyama T, Shimazaki $C$, et al. Feasibility of HLA-haploidentical hematopoietic stem cell transplantation between noninherited maternal antigen (NIMA)-mismatched family members linked with long-term fetomaternal microchimerism. Blood. 2004; 104: 3821-3828.

22. van Rood JJ, Loberiza FR Jr, Zhang MJ, et al. Effect of tolerance to noninherited maternal antigens on the occurrence of graft-versus-host disease after bone marrow transplantation from a parent or an HLA-haploidentical sibling. Blood. 2002; 99: 1572-1577.

23. Kanda Y, Oshima K, Asano-Mori Y, et al. In vivo alemtuzumab enables haploidentical human leukocyte antigen-mismatched hematopoietic stem-cell transplantation without ex vivo graft manipulation. Transplantation. 2005; 79: 1351-1357.

24. Kanda Y, Oshima K, Kako S, et al. In vivo T-cell depletion with alemtuzumab in allogeneic hematopoietic stem cell transplantation: Combined results of two studies on aplastic anemia and HLA-mismatched haploidentical transplantation. Am J Hematol. 2013; 88: 294-300.

25. Ogawa H, Ikegame K, Kaida K, et al. Unmanipulated HLA 23 antigen-mismatched (haploidentical) bone marrow transplantation using only pharmacological GVHD prophylaxis. Exp Hematol. 2008; 36: 1-8.

26. Ogawa H, Ikegame K, Yoshihara S, et al. Unmanipulated HLA 2-3 antigen-mismatched (haploidentical) stem cell transplantation using nonmyeloablative conditioning. Biol Blood Marrow Transplant. 2006; 12: 1073-1084.

27. Duffner U, Lu B, Hildebrandt GC, et al. Role of CXCR3induced donor T-cell migration in acute GVHD. Exp Hematol. 2003; 31: 897-902.

28. Reshef R, Luger SM, Hexner EO, et al. Blockade of lymphocyte chemotaxis in visceral graft-versus-host disease. N Engl J Med. 2012; 367: 135-145.

29. Coghill JM, Carlson MJ, Panoskaltsis-Mortari A, et al. Separation of graft-versus-host disease from graft-versusleukemia responses by targeting CC-chemokine receptor 7 on donor T cells. Blood. 2010; 115: 4914-4922.

30. Cho KA, Woo SY, Park YS, Macrophage inflammatory protein-2 (MIP-2)/CXCR2 blockade attenuates acute graftversus-host disease while preserving graft-versus-leukemia activity. Biochem Biophys Res Commun. 2012; 426: 558-564.

31. Ishikawa Y, Nishio S, Sasaki H, et al. Transplantationassociated thrombotic microangiopathy after steroid pulse therapy for polyserositis related to graft-versus-host disease. Clin Exp Nephrol. 2011; 15: 179-183.

32. Couriel DR, Saliba R, de Lima M, et al. A phase III study of infliximab and corticosteroids for the initial treatment of acute graft-versus-host disease. Biol Blood Marrow Transplant. 2009; 15: 1555-1562.

33. Le Blanc K, Rasmusson I, Sundberg B, et al. Treatment of severe acute graft-versus-host disease with third party haploidentical mesenchymal stem cells. Lancet. 2004; 363: 1439-1441.

34. Le Blanc K, Frassoni F, Ball L, et al. Mesenchymal stem cells for treatment of steroid-resistant, severe, acute graft-versushost disease: a phase II study. Lancet. 2008; 371: 1579-1586. 


\title{
Current status of GVHD control in HLA mismatched stem cell transplantation from family donor
}

Kazuhiro Ikegame MD, PhD.

Division of Hematology, Department of Internal Medicine, Hyogo College of Medicine

\begin{abstract}
To date, a variety of HLA-mismatched (haploidentical, haplo) stem cell transplantation regimens have been reported. The three most common regimens outside of Japan involve 1) ex vivo T cell depletion, 2) high dose anti-thymocyte globulin, and 3) post-transplant cyclophosphamide. According to reports, GVHD is sufficiently controlled, and each regimen could be considered a standard therapy. The magnitude of graft-versus leukemia/lymphoma (GVL) effect in each haplo regimen, however, remains unclear. All of these three regimens are generally used to target patients in complete remission (CR), In Japan, on the other hand, haplo transplants tend to be used for patients not achieving CR or in post-transplant relapse. In the haplo regimen employed at our institute, we have utilized chemokine blockage with steroid-containing GVHD prophylaxis. There are many opportunities to test various GVHD therapies for severe GVHD in haplo transplantation. In this review, I will discuss our experience with thymoglobulin, mycophenolate mofetil, infliximab, oral beclomethasone dipropionate, and mesenchymal stem cells M. (Journal of Hematopoietic Cell Transplantation 2(4): 94-100, 2013.)
\end{abstract}

